\section{Protein Kinase Inhibitors as a Therapeutic Modality}

\section{ALEXANDER LEVITZKI*}

Unit of Cellular Signaling, Department of Biological

Chemistry, The Alexander Silberman Institute of Life Sciences, The Hebrew University of Jerusalem, Jerusalem 91904, Israel

Received March 28, 2003

\section{ABSTRACT}

Most of the signal transduction pathways are mediated by protein kinases regulating every aspect of cell function. Mutations which deregulate their expression or their function or both result in cancers. Therefore, protein kinase inhibitors has become the focus of development of new therapies for cancer. Almost all 120 protein tyrosine kinases are involved in signaling, whereas only a handful of Ser/Thr kinases are involved. Thus, most of the effort is directed toward the development of tyrosine phosphorylation inhibitors. The success of Gleevec in the treatment of chronic myeloid leukemia and of Iressa for lung cancer validates the approach.

\section{Principles of Signal Transduction Therapy}

Cancer cells differ from their normal counterparts in their mode of communication with their neighbors due to aberrations in their signaling network. The realization of aberrant signal transduction as the source of the transformed phenotype of cancer cells has generated mounting interest toward developing therapies targeting these aberrations. ${ }^{1,2}$ Cancer cells develop as a result of a series of mutations in their signaling pathways: (1) cells divide inappropriately with respect to their environmental context, (2) cells develop robust anti-apoptotic signals, avoiding stresses, and (3) cells develop molecular mechanisms to escape the immune system.

These cancer-specific signaling networks can, in principle, become their "Achilles' heel". Identification of these signaling pathways, has become the basis "signal transduction therapy". ${ }^{2}$ Rather than using cytotoxic agents, one targets selectively signaling elements of the cancer cell. ${ }^{3}$ This approach is also applicable to other diseases in which signaling pathways drive the diseased cell. ${ }^{4}$ In the late 1980 s, the most prominent signaling elements, identified as key drivers of the cancer cells, were protein tyrosine kinases (PTKs). Therefore, the first signal transduction inhibitors were tyrosine phosphorylation inhibitors (tyrphostins). ${ }^{5}$ Some tyrphostins were particularly effective since in certain leukemias the targeted PTKs, namely, Jak-2

Alexander Levitzki received his PhD in Biophysics from The Weizmann Institute of Science in 1968. Then he spent three years as a research fellow with $D$. E. Koshland, J r., at the University of California, Berkeley. He is the Wolfson Family Professor of Biochemistry at the Hebrew University of J erusalem. He was awarded the Israel Prize and the Rothschild Prize (1990) for his contribution to enzyme and receptor regulation and the European Society of M edical Oncology Hamilton-Fairly award (2002) for his contribution to cancer therapy. He is a member of the Israel Academy of Sciences and of EMBO. He was a visiting Professor at the University of California-Berkeley, University of Oregon-Eugene, University of Texas MD Anderson Cancer Center, University of California San Francisco, Stanford University, and University of Nice (France) and was a Fogarty International Scholar at the NIH, Bethesda, MD. or Bcr-Abl, were essential for the survival of the leukemic cell. ${ }^{6-8}$ In early stage CML (chronic myeloid leukemia), blockade of Bcr-Abl is sufficient to induce apoptosis and therefore lead to the full remission of patients. ${ }^{9,10}$ Similarly, the blockade of pre-B acute lymphoblastic leukemia by the Jak- 2 inhibitor AG 490 clears the engrafted tumor from the experimental mouse. ${ }^{8}$ The form of therapy aimed at tempering with the signaling pathways of cancer cells was coined as "signal transduction therapy".,2,14 The agents, developed as signal transduction inhibitors, are small molecules, antibodies, proteins, double stranded RNA molecules, and viral (gene) therapy.

\section{II, Protein Tyrosine Kinase Inhibitors Vis-a-Vis SER/THR Inhibitors}

The genome project identifies $\sim 520$ protein kinases from which a few dozens are involved in signal transduction. ${ }^{16}$ PTKs were identified in the 1980s as major players in cancer and, as a result, chosen as therapeutic targets. ${ }^{17}$ EGFR (epidermal growth factor receptor), ${ }^{15} \mathrm{Bcr}-\mathrm{Abl},{ }^{7}$ PDGFR (platelet derived growth factor receptor), ${ }^{18}$ VEGFR (vascular endothelial growth factor receptor), ${ }^{19}$ and IGF-IR (insulin growth factor 1 receptor kinase) ${ }^{23}$ were targeted having established their involvement in various malignancies. Targeting PDGFR was also motivated because of its involvement in restenosis. ${ }^{20-22} \mathrm{~A}$ small group of serine / threonine kinases, cyclin dependent kinase (Cdks), Erks, Raf, and PKB/Akt, were identified as major players in cell proliferation, cell division, and anti-apoptotic signaling. These Ser/Thr kinases are downstream to PTKs (Figure 1). Some believe that it is reasonable to target the upstream PTK rather than the downstream Ser/Thr kinase. Shutting off the elevated activity of the overactive PTK will nullify all the elements whose activities become enhanced as a result of the enhanced activity of the PTK targeted. When other mechanisms contribute to the activation of the Ser/Thr kinase, it is reasonable to utilize a Ser/Thr kinase inhibitor. One notable example is PKB (protein kinase B). PKB is most important in the antiapoptotic network, and its activity is highly elevated, especially in metastatic cancer. The elevated activity of PKB results from enhanced signaling of upstream PTKs combined with the deletion of PTEN (phosphatase and tensin homologue), its negative regulator (Figure 1).

\section{Development of PTK Inhibitors}

Early searches for PTK inhibitors identified natural compounds such as quercetin, genistein, erbstatin, and lavendustin. These compounds were found to be highly promiscuous, inhibiting many protein kinases, which was not surprising to the research community in those days. It was then believed that it was impossible to generate selective small molecules targeting protein kinases. Emphasis was put on the conservation of the ATP binding

\footnotetext{
*E-mail: levitzki@vms.huji.ac.il. Telephone: +972-2-6585404. Fax: +972-2-6512958.
} 


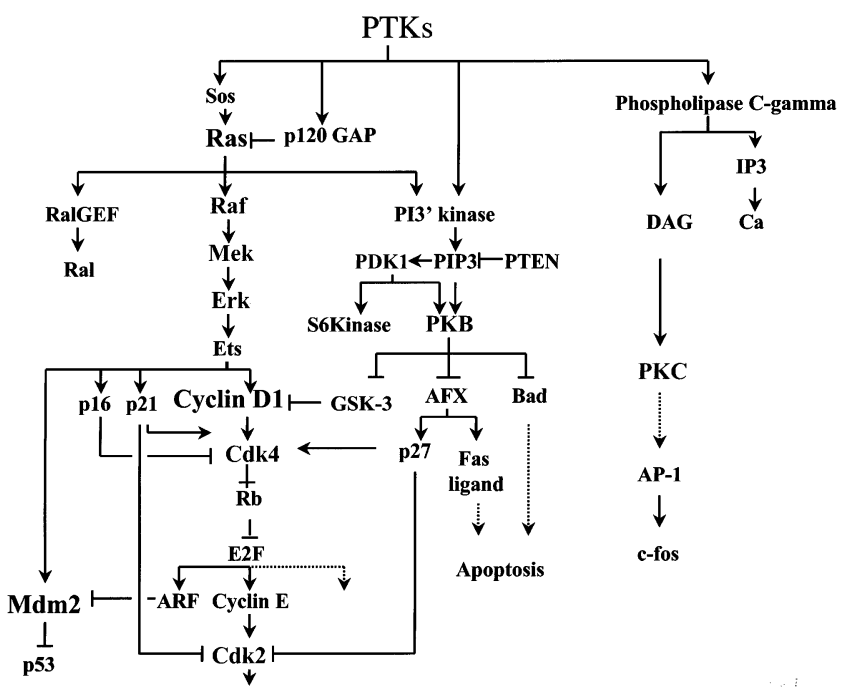

FIGURE 1. Protein kinases as signal transducers PTKs are upstream to a small number of Ser/Thr kinases which transmit their signal. The activity of some Ser/Thr kinases is enhanced by the deletion of negative regulators, like p16 and PTEN. When Ras or Raf are persistently active due to a mutation, the signaling downstream is independent of the upstream PTK.

site among the different protein kinases. The first selective PTK inhibitors discovered were the benzene malononitrile tyrphostins which block effectively the EGFR. $15,24,25$ These compounds (Figure 2) were competitive with the substrate and noncompetitive with ATP, poorly blocking insulin receptor kinase and having no measurable activity against CAMP-dependent protein kinase. Many tyrphostins were found to be ATP-competitive, substrate-competitive, or competitive against both. ${ }^{26}$ Some were found to be "mixed-competitive" against EGFR ${ }^{26}$ and PDGFR. ${ }^{27}$ Most cyclized tyrphostins, incorporating the nitrile nitrogen into a second ring, are ATP-competitive. . $^{8,28,29}$ Since 1994 the main thrust in the development of PTK inhibitors has been toward the generation of ATP-mimics. ${ }^{17}$ Since the degree of conservation in the ATP binding site is not absolute, one can obtain a high degree of selectivity among closely related ATP binding domains. In 1993 we demonstrated that ATP-competitive tyrphostins discriminate between the kinase domains of EGFR and its closely related Her$2 /$ neu by 2 orders of magnitude in affinity. ${ }^{30}$ Quinazolines were shown to selectively inhibit EGFR in the low nanomolar concentration range. ${ }^{28,31}$ ZD 1839 (Iressa), a potent EGFR kinase inhibitor with excellent bioavailability, was chosen for clinical development. ${ }^{31}$ Qunixaloines such as AG 1295 and AG 129618,32 or AGL $2043^{33}$ (Figure 4) block PDGFR kinase with excellent inhibitory effects on the related c-Kit and Flt-3 receptors and much less efficacy against VEGFR. ${ }^{34}$ The crystal structure of the of Hck with the Src family inhibitor PP1 $1^{35}$ and of Gleevec with $\mathrm{Abl}^{36}$ revealed why these ATP analogues are highly selective. However, both $\mathrm{PP}^{37}$ and STI 571, ${ }^{38}$ which are very different in structure (Figure 2), bind also to PDGFR. This finding should alert us to possible problems when novel kinase inhibitors are not tested on as many kinases as possible before they move forward in the development process.

\section{Current PTK Inhibitors-Where Do We Go Now?}

The success of Gleevec/ Glivec in treating early CML and gastrointestinal stromal tunors (GIST), as well as the moderate success of Iressa (ZD 1839), validate the approach. We still need to assess whether more scaffolds for the design of novel PTK inhibitors are needed. Iressa has only moderate success in treating lung cancer as a single agent and is ineffective when combined with CDDP. Thus, we need also to learn more about the role of EGFR in the various forms of lung cancer and determine which subclass of patients should be selected for the treatment. It is highly likely that signaling elements other than EGFR and Her-2 should be considered. ${ }^{39}$

\section{EGFR Family Kinase Inhibitors}

The role of EGFR in many cancers has been appreciated early on and, therefore, was one of the first targets

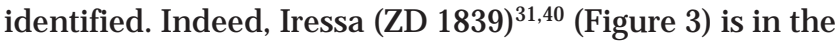
clinic for the treatment of nonsmall cell lung carcinoma, and the quinazoline AG $1478^{29}$ is in clinical development for the treatment of glioblastoma multiforme (GBM) in which the persistently active $\Delta(2-7)$ EGFR is overexpressed. ${ }^{41,42}$ AG 1478 will be used in combination with CDDP, with which it synergies to induce apoptosis in GBM in vitro and in vivo. ${ }^{42}$ Since heterodimer combinations of the four members of the Her family play a role in the oncogenic phenotype of many cancers, there have been attempts to generate inhibitors of both Her-1 and Her-2 like GW 2016 (Figure 3), which blocks both EGFR and Her-2 12nM. ${ }^{43}$

\section{Irreversible EGFR Kinase Inhibitors}

The covalent attachment of a selective inhibitor to the EGFR kinase domain abolishes completely the catalytic activity and, therefore, is believed to possess better clinical potential. Indeed, $\mathrm{Cl}-1033$ (Figure 5$)^{44}$ is effective in preclinical in vivo experiments. $\mathrm{Cl}-1033$, however, is, quite toxic (unpublished), most probably due to the high chemical reactivity of the acryloyl group. To improve the profile of such compounds, one may have to reduce the chemical reactivity of the labeling group. In doing so, the reaction of the inhibitor with nonspecific targets should be reduced. Recently, this has been successfully achieved by enhancing the affinity of the quinazoline but in parallel reducing the chemical reactivity of the labeling group. Enhanced affinity is due to diminished $k_{\text {off, }}$ which keeps the compound at the active long enough to allow interaction with cysteine 773 , even with a chemical group which is less reactive than the acryloyl moiety. The diminished chemical reactivity has a chance to reduce the toxicity of the compound, compared with $\mathrm{Cl}-1033$.

\section{From Tyrphostins to Gleevec}

In the early 1990s, the Bcr-Abl kinase inhibitors, tyrphostin AG 1112, AG 1318, ${ }^{6}$ and AG $957^{7,45}$ (Figure 6), were shown 


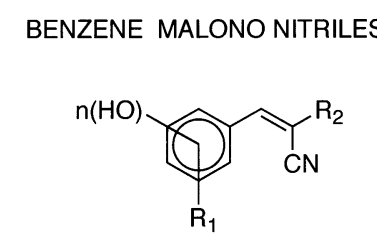

(Original Tyrphstins)

PYRAZOLO PYRIMIDINES<smiles>[R7]c1ccc(-c2nn([R6])c3ncnc(N)c23)cc1</smiles>

QUINAXOLINES<smiles>[R6]c1ccc(-c2cnc3cc([R6])c([R])cc3n2)cc1</smiles>

\section{LAVENDUSTINS}<smiles>[R5]c1cc(O)cc(CN(Cc2ccc([R5])cc2O)c2cc([R7])c(O)c(C(=O)O)c2)c1</smiles>

PYRIDO PYRIMIDINES<smiles>[R2]c1ccc(C(=O)Nc2ccc(Br)c(Nc3nccc(-c4cccnc4)n3)c2)cc1</smiles>

BENZO QUINAXOLINES

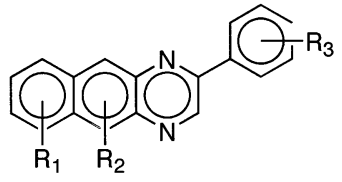

ANILIDO PHTHALIMIDES<smiles>[R2]c1ccc(Nc2cc3c(cc2Nc2ccc(Br)cc2)C(=O)NC3=O)cc1</smiles>

QUINAZOLINES<smiles>[R6]c1cc([R])cc(-c2cc3cnc([B])nc3nc2[R3])c1</smiles>

PYRROLO ISATINES<smiles>[R5]c1ccc2c(c1)/C(=C/c1[nH]c([R6])cc1[R])C(=O)N2</smiles>

FIGURE 2. Protein tyrosine kinase inhibitors dDifferent core structures used by investigators in the field are shown.

to induce the terminal differentiation of $\mathrm{K} 562$ cells, the purging of $\mathrm{Ph}+$ cells, and synergies with the anti-Fas receptor antibody in order to induce their demise. ${ }^{46}$ These compounds were not developed for the clinic since it was not believed at that time that they have a commercial future because of the rarity of CML compared to other cancers. Druker and Lydon followed up these studies, utilizing the Ciba-Geigy (than Novartis) compound CGP 57148 (Figure 6). This compound, ${ }^{47}$ renamed STI 571/Gleevec/Glivec, became the first signal transduction inhibitor to show excellent efficacy in the clinic ${ }^{9,10}$ for early CML. The absence of severe side effects in these patients was unexpected in view of the strong inhibitory activity of the compounds toward c-Abl, PDG$\mathrm{FR}$, and C-Kit. This is probably due to the ability of normal cells to sustain high levels of inhibition of these elements, whereas the CML cells' survival depends on BcrAbl. Thus, the principle of the enhanced sensitivity of the cancer cell to an inhibitor, which targets the element whose signaling is enhanced, ${ }^{48}$ is validated in the clinic. Gleevec is highly active on a subpopulation of gastrointestinal stromal tumor (GIST) patients. ${ }^{49}$ The patients who respond best to STI 571 express Kit receptors, which carry mutations in exon 11, converting the receptor to a persistently active kinase essential for the survival of the cancer cell.

\section{ATP Mimics and Substrate Mimics}

Currently, all PTK inhibitors in clinical development or heading toward the clinic are competitive inhibitors of ATP and noncompetitive vis-à-vis the substrate. Although substrate competitive inhibitors never made it to the clinic, they are likely to be less toxic than ATP-mimics, since they bind to domains at the kinase site that are less conserved than the ATP binding site and are therefore less likely to hit many other targets. Indeed, tyrphostins such as AG 490, which blocks Jak-2,8 and AG 556, which possesses antiinflammatory properties, have been shown to be highly nontoxic in vivo. ${ }^{50-53} \mathrm{~A}$ major concern with these compounds, voiced in the literature, is that they possess hydroxyl groups, which are metabolically unstable. Although DOPA, a catechol, is a success story, the current feeling is than one should aim at tyrphostins with diminished numbers of hydroxyl groups. This has been partially accomplished by developing substrate mimics in which the hydroxyls are replaced by "bioisosteres". ${ }^{54}$ AG 538, which is a competitive inhibitor of the IGF1-R, ${ }^{55}$ was converted quite successfully to "bioisosteres", retaining the substrate competitive nature of the compound ${ }^{54}$ (Figure 7), but loosing some efficacy. When one examines the efficacy of the ATP-competitive inhibitors in cellular assays, it is observed that these nanomolar compounds act on cells in the micromolar concentration range, most 
<smiles>COc1cc2ncnc(Nc3ccc(F)c(Cl)c3)c2cc1CCCCN1CCOCC1</smiles>

ZD 1839 (Iressa)<smiles>C#Cc1cccc(Nc2ncnc3cc(OCCOC)c(OCCOC)cc23)c1</smiles><smiles>C[C@@H](CNCC[Si](C)(O)O)C(C)(C)C</smiles>

GW 2016

FIGURE 3. Quinazoline EGFR kinase family inhibitors.<smiles>COc1cc2ncc(-c3ccccc3)nc2cc1OC(C)(C)C</smiles>

FIGURE 4. Quinoxaline PDGFR kinase inhibitors.<smiles>COC/C=C\C(=O)Nc1cc2c(Nc3ccc(F)c(Cl)c3)ncnc2cc1OCCC(C)C</smiles>

FIGURE 5. Irreversible EGFR kinase inhibitor.

probably because they need to compete against milllimolar concentrations of ATP. For example, quinazolines, which bind to the EGFR with $\mathrm{Ki}$ of a few nanomolar, ${ }^{28}$ inhibit EGFR autophosphorylation in intact cells at the micromolar concentrations. ${ }^{29,56}$ Similarly, PP1, which inhibits Src family kinases at 20-170 nM in cell-free assays, ${ }^{57}$ inhibit Src activity in cells in the range of $5-40 \mu \mathrm{M} .56,58$ Another issue is that the selectivities of newly developed compounds are tested only against a limited number of PTKs and Ser/Thr kinases. Many selective inhibitors are soon discovered to hit other kinases: PP1 is equipotent as a PDGFR kinase inhibitor, ${ }^{37}$ and Gleevec is as potent

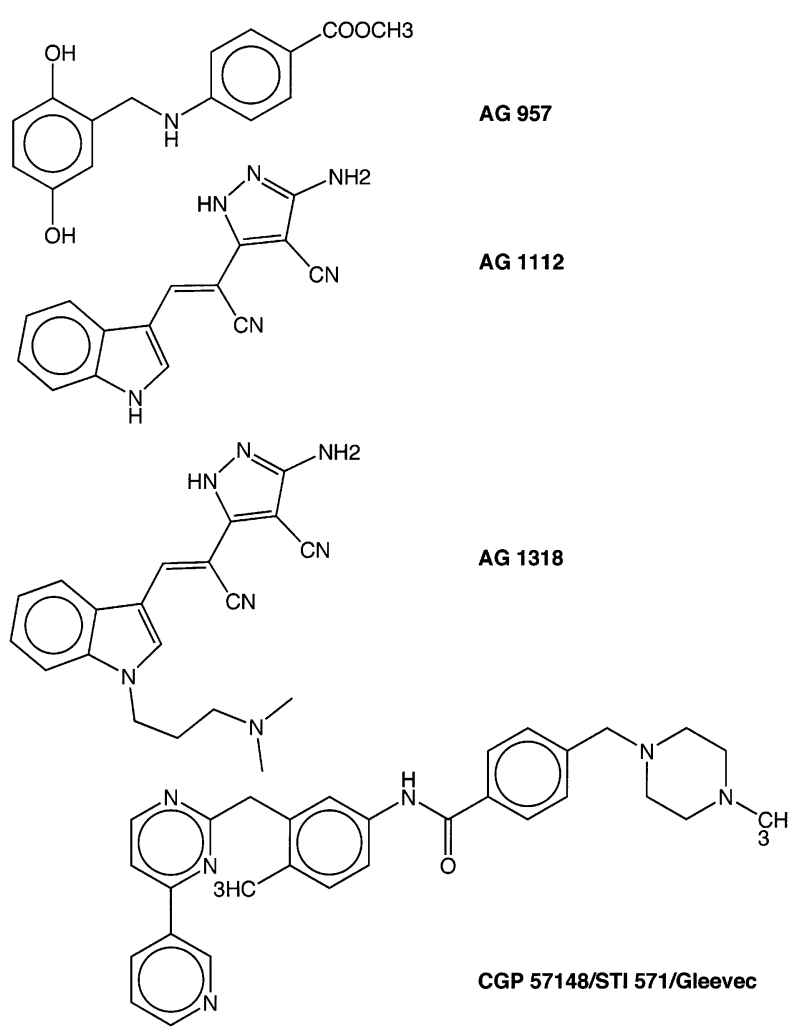

FIGURE 6. Bcr-Abl kinase inhibitors.<smiles>N#C/C(=C\c1ccc(O)c(O)c1)C(=O)c1ccc(O)c(O)c1</smiles><smiles>N#C/C(=C\c1ccc(O)c(O)c1)C(=O)c1ccc2[nH]c(=O)oc2c1</smiles>

640<smiles>N#C/C(=C\c1ccc2oc(=O)[nH]c2c1)C(=O)c1ccc2[nH]c(=O)oc2c1</smiles>

FIGURE 7. Bio-isostere substrate competitive inhibitors. AG 538 was found to be a potent substrate competitive inhibitor of IGF-1 receptor. The replacement of one catechol moiety did not result in a large reduction in affinity, but the replacement of both resulted in a severe loss of activity. All, however, retain their substrate competitive kinetics.

against PDGFR kinase and C-Kit. ${ }^{49}$ Substrate competitive inhibitors have the potential to be more selective since the domain outside the ATP binding site is less conserved and may offer more opportunities to design a selective 
<smiles>CN1CCC(c2c(O)cc(O)c3c(=O)cc(-c4ccccc4Cl)oc23)C(O)C1</smiles>

Flavopiridol<smiles>NC(=O)c1cc(Oc2ccc(NC(=O)Nc3ccc(Cl)c(C(F)(F)F)c3)cc2)ccn1</smiles>
BAY 43-9006<smiles>O=C(NOC1CC1)c1ccc(F)c(F)c1Nc1ccc(I)cc1Cl</smiles>

PD 184352

FIGURE 8. Ser/Thr kinase inhibitors.

inhibitor. Bi-substrate inhibitors, which compete for both ATP and substrate simultaneously may be inferior, in principle, to substrate mimics, since they still have to compete against high intracellular ATP levels.

\section{PTK Inhibitors Synergize with Pro-Apoptotic Agents}

Transformed cells are more sensitive to stress signaling pathways and apoptotic signals as compared to their parental nonmalignant cells. ${ }^{48,60}$ Therefore, transformed cells are more sensitive to cytotoxic agents such as CDDP, other pro-apoptotic cytotoxic agents, and the pro-apoptotic ligand FasL (see ${ }^{48}$ for review). However, as the cancer progresses to a more advanced state, cells acquire an antiapoptotic shield, masking the potentiated state of sensitiv- ity. ${ }^{48} \mathrm{An}$ interesting example is advanced GBM, where the truncated EGFR, $\Delta(2-7)$ EGFR, is responsible for its resistance to chemotherapy and radiation therapy. Blockade of the $\Delta(2-7)$ EGFR by the EGFR kinase inhibitor AG 1478 sensitizes the tumor to CDDP and enhances the survival of tumor bearing nude mice treated with the two agents. ${ }^{41,42}$

\section{PTK Inhibitors for the Treatment Restenosis, Psoriasis, and Papilloma}

Restenosis, following balloon angioplasty, is largely driven by the stimulation of the PDGFR in the media of the manipulated blood vessel. Indeed, local application of the PDGFR kinase inhibitors AG $1295^{22}$ and AGL 204333,34 (Banai et al., unpublished experiments), during balloon angioplasty, inhibits effectively restenosis. Enhanced activity of EGFR observed in psoriasis and Papilloma is due to the autocrinic stimulation of an EGFR, which is overexpressed. EGFR kinase inhibitors inhibit the growth of both psoriatic keratinocytes ${ }^{61-64}$ and keratinocytes, immortalized with HPV 16, ${ }^{65,66}$ and therefore can be considered as therapeutic agents.

\section{EGFR Kinase Inhibitors for Imaging}

In principle, one can utilize radioactively labeled PTK inhibitors in order to image tumors, which overexpress the kinase and determine whether targeting a particular kinase is reasonable. A case in point is the decision whether to treat lung cancer with I ressa since not every lung cancer expresses these receptors. ${ }^{39}$ Reversible and irreversible $11 \mathrm{C}$ and $18 \mathrm{~F}$ labeled EGFR kinase inhibitors were recently developed for imaging EGFR overexpressing tumors. It was recently shown that the irreversible inhibitors ${ }^{67}$ are actually superior to the reversible ones. ${ }^{68}$

\section{SER/THR Kinase Inhibitors}

A handful of Ser/Thr kinases have been shown to be to be involved in signal transduction as we know it today (Figure 1). These transmit signals of upstream PTKs, and their activity is essential for cell proliferation and the onset of anti-apoptotic signaling (Figure 1). Their

Table 1. Protein Kinase Inhibitors in the Clinic and in Development

\begin{tabular}{|c|c|c|c|c|}
\hline company & agent & indication & target & status \\
\hline \multicolumn{5}{|c|}{ PTK Inhibitors } \\
\hline Novartis & STI571/Gleevec & CML* & Bcr-Abl & marketed \\
\hline Novartis & STI571/Gleevec & GIST & C-Kit & marketed \\
\hline AstraZeneca & ZD 1839// ressa & solid tumors & EGFR,Her-2 & marketed \\
\hline Pharmacia/Sugen & SU 6668 & solid tumors & VEGFR/PDGFR/FGFR & phase 3 \\
\hline OSI Pharmaceuticals & Tarceva (OSI 774) & solid tumors & EGFR & phase 2 \\
\hline Cephalon/Lundbeck & CEP-701 & prostate cancer & NGFR & phase 2 \\
\hline Ludwig I nstitute & AG 1478/CDDP & glioblastoma multiforme & EGFR & phase 1 \\
\hline \multicolumn{5}{|c|}{ Ser/Thr Kinase Inhibitors } \\
\hline Bayer/Onyx & BAY 43-9006 & colon cancer & Raf & phase 1 \\
\hline Falvopiridol & & & $\mathrm{Cdk} 4 / 1$ & phase 1 \\
\hline Eli Lilly & LY 333531 & diabetic retinopathy & protein kinase $\mathrm{C}$ & phase 3 \\
\hline Cephalon/Lundbeck & CEP-1347 & Parkinson's & mixed lineage kinase & phase 1 \\
\hline
\end{tabular}


abnormal enhanced activities are enhanced by the de letion of negative regulators, such as protein inhibitors of cyclin-dependent kinases (Cdks), like p16, and the deletion of the tumor suppressor PTEN (Figure 1). Thus, the enhanced activities of these kinases are driven by the synergistic action of the upstream PTKs, combined with the inactivation of the downstream negative regulators.

\section{XIII, RAF and MEK Inhibitors}

Inhibitors of the Ras-Raf-Mek-Erk pathway are of great potential since the activation of elements of this pathway is the hallmark of many cancers. For example, activating mutations in B-Raf occur in $\sim 66 \%$ of human melanoma, ${ }^{69}$ suggesting that Raf kinase inhibitors such as BAY 43-900670 (Figure 8) and Mek inhibitors such as PD184352 ${ }^{71}$ (Figure 8) may be useful. PD 184352 inhibits tumor growth in mice with colon carcinomas of both mouse and human origin. ${ }^{71}$ Raf, Mek, and Erk inhibitors can be extremely useful for the treatment of many cancers since their activities are highly enhanced due to the widespread oncogenic mutations in ras. Once activating mutations occur in the Ras-Raf-M ek pathway, the utilization of SerThr inhibitors will be essential since the pathway will be independent of PTK activation.

\section{Cyclin Dependent Kinase Inhibitors}

Inhibitors of Cdks, especially Cdk2 and Cdk 4, are in clinical development for cancer. ${ }^{72-77}$

Falvopiridol, for example, (Figure 8) inhibits Cdk4/ cyclin D and Cdk1/CyclinB1 ${ }^{78}$ and is currently in clinical trials. ${ }^{79}$

\section{PKB/AKT Inhibitors}

Progress toward the generation of PKB inhibitors (Aktstatins) has been recently reported. The PKA inhibitor $\mathrm{H}-89$ was modified to reduce its affinity toward PKA and improve its affinity toward $\mathrm{PKB} / \mathrm{Akt}{ }^{80}$

\section{XVI, PKC Inhibitors}

Although PKC isozymes have been known for a long time, little progress has been made in the utilization of PKC inhibitors, but some PKC inhibitors are in development as anticancer agents ${ }^{73,81-83}$ and vascular retinopathy. ${ }^{84}$

\section{Rapamycin}

Rapamycin, the inhibitor of mTor, is effective as an inhibitor of angiogenesis and therefore is a potential anticancer drug. ${ }^{85}$ Rapamycin is also effective in the inhibition of restenosis, when applied on coated stents.

Table 1 summarizes the current state of protein kinase inhibitors in the clinic.

\section{Concluding Remarks}

The success of Gleevec, in treating patients suffering from chronic myeloid leukemia, and of Iressa, in the treatment of a sub-population of lung cancer patients, demonstrates the paradigm shift taking place in cancer therapy. Since protein kinases, especially protein tyrosine kinases, play a role in every aspect of cellular function, their malfunction results in disease, often cancer. Thus, protein tyrosine phosphorylation inhibitors will occupy an increasing fraction of anticancer agents of the future. It is quite clear that a few dozens of such inhibitors, covering most of the kinases involved in the various cancers, will make a huge difference in disease outcome in the coming future. Table 1 summarizes the current protein kinase inhibitors in the clinic and in development.

\section{References}

(1) Levitzki, A.; Gilon, C. Tyrphostins as molecular tools and potential antiproliferative drugs. Trends Pharmacol. Sci. 1991, 12, 171-4.

(2) Levitzki, A. Signal-transduction therapy. A novel approach to disease management. Eur. J. Biochem. 1994, 226, 1-13.

(3) Levitzki, A. Signal transduction interception as a novel approach to disease management. Ann. N.Y. Acad. Sci. 1995, 766, 363-8.

(4) Levitzki, A. Tyrphostins-potential antiproliferative agents and novel molecular tools. Biochem. Pharmacol. 1990, 40, 913-8.

(5) Levitzki, A. Tyrphostins: tyrosine kinase blockers as novel antiproliferative agents and dissectors of signal transduction. Faseb J. 1992, 6, 3275-82.

(6) Anafi, M.; Gazit A.; Zehavi A.; Ben-Neriah Y.; Levitzki A. Tyrphostin-induced inhibition of p210bcr-abl tyrosine kinase activity induces K562 to differentiate. Blood 1993, 82, 3524-9.

(7) Anafi, M.; Gazit A.; Gilon C.; Ben-Neriah Y.; Levitzki A. Selective interactions of transforming and normal abl proteins with ATP, tyrosine-copolymer substrates, and tyrphostins. J. Biol. Chem. 1992, 267, 4518-23.

(8) Meydan, N.; Grunberger, T.; Dadi, H.; Shahar, M.; Arpaia, E.; Lapidot, Z.; Leeder, J. S.; Freedman, M.; Cohen, A.; Gazit, A.; Levitzki, A.; Roifman, C. M. Inhibition of acute Iymphoblastic leukaemia by a J ak-2 inhibitor. Nature 1996, 379, 645-8.

(9) Druker, B. J .; Lydon, N. B. Lessons learned from the development of an abl tyrosine kinase inhibitor for chronic myelogenous leukemia. J. Clin. Invest. 2000, 105, 3-7.

(10) Druker; B. J . Perspectives on the development of a molecularly targeted agent. Cancer Cell 2002, 1, 31-36.

(11) Catlett-Falcone R.; Landowski T. H.; Oshiro M. M.; Turkson J .; Levitzki A.; Savino R.; Ciliberto G.; Moscinski L.; Fernandez-Luna J. L.; Nunez G.; Dalton W. S.; J ove R. Constitutive activation of Stat3 signaling confers resistance to apoptosis in human U266 myeloma cells. Immunity 1999, 10, 105-15.

(12) Burdelya, L.; Catlett-Falcone, R.; Levitzki, A.; Cheng, F.; Mora, L. B.; Sotomayor, E.; Coppola, D.; Sun, J .; Sebti, S.; Dalton, W. S.; J ove, R.; Yu, H. Combination therapy with AG-490 and interleukin 12 achieves greater antitumor effects than either agent alone. Mol. Cancer Ther. 2002, 1, 893-9.

(13) Tsai, C. M.; Levitzki, A.; Wu, L. H.; Chang, K. T.; Cheng, C. C.; Gazit A.; Perng, R. P. Enhancement of chemosensitivity by tyrphostin AG825 in high-p185(neu) expressing non-small cell lung cancer cells. Cancer Res. 1996, 56, 1068-74.

(14) Levitzki, A.; Gazit, A. Tyrosine kinase inhibition: an approach to drug development. Science 1995, 267, 1782-8.

(15) Yaish, P.; Gazit, A.; Gilon, C.; Levitzki, A. Blocking of EGFdependent cell proliferation by EGF receptor kinase inhibitors. Science 1988, 242, 933-5.

(16) Manning, G.; Whyte, D. B.; Martinez, R.; Hunter, T.; Sudasanam, $\mathrm{S}$. The protein kinase complement of the human genome. Science 2002, 298, 1912-1934.

(17) Levitzki, A. Protein tyrosine kinase inhibitors as novel therapeutic agents. Pharmacol. Ther. 1999, 82, 231-9.

(18) Kovalenko, M.; Gazit, A.; Bohmer, A.; Rorsman, C.; Ronnstrand, L.; Heldin, C. H.; Waltenberger, J .; Bohmer, F. D.; Levitzki, A. Selective platelet-derived growth factor receptor kinase blockers reverse sis-transformation. Cancer Res. 1994, 54, 6106-14.

(19) Strawn, L. M.; McMahon, G.; App, H.; Schreck, R.; Kuchler, W. R.; Longhi, M. P.; Hui, T. H.; Tang, C.; Levitzki, A.; Gazit, A.; Chen I.; Keri, G.; Orfi, L.; Risau, W.; Flamme, I.; Ullrich, A.; Hirth, K. P.; Shawver, L. K. Flk-1 as a target for tumor growth inhibition. Cancer Res. 1996, 56, 3540-5. 
(20) Bilder G. E.; Krawiec J . A.; McVety K.; Gazit A.; Gilon C.; Lyall R.; Zilberstein A.; Levitzki A.; Perrone M. H.; Schreiber A. B. Tyrphostins inhibit PDGF-induced DNA synthesis and associated early events in smooth muscle cells. Am. J . Physiol. 1991, 260, C721-30.

(21) Bryckaert M. C.; Eldor A.; Fontenay M.; Gazit A.; Osherov N.; Gilon C.; Levitzki A.; Tobelem G. Inhibition of platelet-derived growth factor-induced mitogenesis and tyrosine kinase activity in cultured bone marrow fibroblasts by tyrphostins. Exp. Cell Res. 1992, 199, 255-61.

(22) Banai S.; Wolf Y.; Golom, G.; Pearle A.; Waltenberger J .; Fishbein I.; Schneider A.; Gazit A.; Perez L.; Huber, R.; Lazarovichi G.; Rabinovich, L.; Levitzki A.; Gertz S. D. PDGF-receptor tyrosine kinase blocker AG1295 selectively attenuates smooth muscle cell growth in vitro and reduces neointimal formation after balloon angioplasty in swine. Circulation 1998, 97, 1960-9.

(23) Parrizas, M.; Gazit, A.; Levitzki, A.; Wertheimer, E.; LeRoith, D. Specific inhibition of insulin-like growth factor-1 and insulin receptor tyrosine kinase activity and biological function by tyrphostins. Endocrinology 1997, 138, 1427-33.

(24) Gazit, A.; Yaish, P.; Gilon, C.; Levitzki, A. Tyrphostins I: synthesis and biological activity of protein tyrosine kinase inhibitors. J . Med. Chem. 1989, 32, 2344-52.

(25) Gazit, A.; Osherov, N.; Posner, I.; Yaish, P.; Poradosu, E.; Gilon, C.; Levitzki, A. Tyrphostins. 2. Heterocyclic and alpha-substituted benzylidenemalononitrile tyrphostins as potent inhibitors of EGF receptor and ErbB2/neu tyrosine kinases. J. Med. Chem. 1991 34, 1896-907.

(26) Posner, I.; Levitzki, A. Kinetics of phosphorylation of the SH2containing domain of phospholipase $\mathrm{C}$ gamma 1 by the epidermal growth factor receptor. FEBS Lett. 1994, 353, 155-61.

(27) Kovalenko, M.; Ronnstrand, L.; Heldin, C. H.; Loubtchenkov, M.; Gazit, A.; Levitzki, A.; Bohmer, F. D. Phosphorylation site-specific inhibition of platelet-derived growth factor beta-receptor autophosphorylation by the receptor blocking tyrphostin AG1296. Biochemistry 1997, 36, 6260-9.

(28) Ward, W. H.; Cook, P. N.; Slater, A. M.; Davies, D. H.; Holdgate, G. A.; Green, L. R. Epidermal growth factor receptor tyrosine kinase. Investigation of catalytic mechanism, structure-based searching and discovery of a potent inhibitor. Biochem. Pharmacol. 1994, 48, 659-66.

(29) Osherov, N.; Levitzki, A. Epidermal-growth-factor-dependent activation of the src-family kinases. Eur. J . Biochem. 1994, 225, 1047-53.

(30) Osherov, N.; Gazit, A.; Gilon, C.; Levitzki, A. Selective inhibition of the epidermal growth factor and HER2/neu receptors by tyrphostins. J. Biol. Chem. 1993, 268, 11134-42.

(31) Woodburn, J. R.; Barker, A. J .; Gibson, K. H.; Ashton, S. E.; Wakeling, A. E.; Curry, B. J .; Scerlett, L.; Henthorn, L. R. Abstract 4251. Proc. 88th Annu. Meet. AACR 1997, 38.

(32) Gazit, A.; App, H.; McMahon, G.; Chen, J .; Levitzki, A.; Bohmer, F. D. Tyrphostins. 5. Potent inhibitors of platelet-derived growth factor receptor tyrosine kinase: structure-activity relationships in quinoxalines, quinolines, and indole tyrphostins. J. Med. Chem. 1996, 39, 2170-7.

(33) Levitzki, A.; Gazit, A.; Banai, S.; Golomb, G.; Gertz, D. U.S. Patent 6,358,954, 2002.

(34) Gazit, A.; Yee K.; Uecker, A.; Bohmer, F. D.; Sjoblom, T.; Ostman, A.; Waltenberger, J .; Golomb, G.; Banai, S.; Heinrich, M. C.; Levitzki, A. Tricyclic Quinoxalines as potent kinase inhbitors of PDGFR kinase Flt-3 and kit. Bioorg. Med. Chem. 2003, 11 (9), 2007-18.

(35) Schindler, T.; Sicheri, F.; Pico, A.; Gazit, A.; Levitzki, A.; Kuriyan, $\mathrm{J}$. Crystal structure of Hck in complex with a Src family-selective tyrosine kinase inhibitor. Mol. Cell 1999, 3, 639-48.

(36) Schindler, T.; Bornmann, W.; Pellicena, P.; Miller, W. T.; Clarkson, B.; Kuriyan, J. Structural mechanism for STI-571 inhibition of abelson tyrosine kinase. Science 2000, 289, 1938-42.

(37) Waltenberger, J .; Uecker, A.; Kroll, J .; Frank, H.; Mayr, U.; Bjorge, J . D.; Fujita, D.; Gazit, A.; Hombach, V.; Levitzki, A.; Bohmer, F. D. A dual inhibitor of platelet-derived growth factor beta-receptor and Src kinase activity potently interferes with motogenic and mitogenic responses to PDGF in vascular smooth muscle cells. A novel candidate for prevention of vascular remodeling. Circ. Res. 1999, 85, 12-22.

(38) Carroll M.; Ohno-J ones S.; Tamura S.; Buchdunger E.; Zimmermann J .; Lydon N. B.; Gilliland D. G.; Druker B. J . CGP 57148, a tyrosine kinase inhibitor, inhibits the growth of cells expressing BCR-ABL, TEL-ABL, and TEL-PDGFR fusion proteins. Blood 1997, 90, 4947-52.

(39) Levitzki, A. EGF Receptor As A Therapeutic Target. Lung Cancer 2003, in press.
(40) Wakeling, A. E.; Guy, S. P.; Woodburn, J . R.; Ashton, S. E.; Curry, B. J .; Barker, A. J .; Gibson, K. H. ZD1839 (Iressa): an orally active inhibitor of epidermal growth factor signaling with potential for cancer therapy. Cancer Res. 2002, 62, 5749-54.

(41) Nagane, M.; Levitzki, A.; Gazit, A.; Cavenee, W. K.; Huang, H. J . Drug resistance of human glioblastoma cells conferred by a tumor-specific mutant epidermal growth factor receptor through modulation of $\mathrm{Bcl}-\mathrm{XL}$ and caspase-3-like proteases. Proc. Natl. Acad. Sci. U.S.A. 1998, 95, 5724-9.

(42) Nagane, M.; Narita, Y.; Mishima, K.; Levitzki, A.; Burgess, A. W.; Cavenee, W. K.; Huang, H. J . Human glioblastoma xenografts overexpressing a tumor-specific mutant epidermal growth factor receptor sensitized to cisplatin by the AG1478 tyrosine kinase inhibitor. J . Neurosurg. 2001, 95, 472-9.

(43) Keith, B. R.; Allen, P. P.; Aliigood, K. J .; Crosby, R. M.; Lackey, K.; Gilmer, T. M.; Mullin, R. J . Abstract 4308. Proc. 92nd Annu. Meet. AACR 2001, 42, 803.

(44) Wissner, A.; Brawner Floyd, M.; Rabindran, S.; Nilakantan, R Greenberger, L.; Shen, R.; Wang, Y.; Tsou, H. Syntheses and EGFR and HER-2 kinase inhibitory activities of 4-anilinoquinoline-3carbonitriles: analogues of three important 4-anilinoquinazolines currently undergoing clinical evaluation as therapeutic antitumor agents. Bioorg. Med. Chem. Lett. 2002, 12, 2893-7.

(45) Kaur, G.; Gazit, A.; Levitzki, A.; Stowe, E.; Cooney, D. A.; Sausville, E. A. Tyrphostin induced growth inhibition: correlation with effect on p210bcr-abl autokinase activity in K562 chronic myelogenous leukemia. Anticancer Drugs 1994, 5, 213-22.

(46) Carlo-Stella C.; Regazzi E.; Sammarelli G.; Colla S.; Garau D.; Gazit A.: Savoldo B.: Cilloni D.: Tabilio A.; Levitzki A.; Rizzoli V. Effects of the tyrosine kinase inhibitor AG957 and an Anti-Fas receptor antibody on $\mathrm{CD} 34(+)$ chronic myelogenous leukemia progenitor cells. Blood 1999, 93, 3973-82.

(47) Druker, B. J .; Tamura, S.; Buchdunger, E.; Ohno, S.; Segal, G. M.; Fanning, S.; Zimmermann, J .; Lydon, N. B. Effects of a selective inhibitor of the Abl tyrosine kinase on the growth of Bcr-Abl positive cells. Nat. Med. 1996, 2, 561-6.

(48) Benhar, M.; Engelberg, D.; Levitzki, A. ROS, stress-activated kinases and stress signaling in cancer. EMBO Rep. 2002, 3, 4205.

(49) Heinrich, M. C.; Griffith, D. J .; Druker, B.J .; Wait, C. L.; Ott, K. A.; Zigler, A. J . Inhibition of c-kit receptor tyrosine kinase activity by STI 571, a selective tyrosine kinase inhibitor. Blood 2000, 96, 92532.

(50) Novogrodsky, A.; Vanichkin, A.; Patya, M.; Gazit, A.; Osherov, N.; Levitzki, A. Prevention of lipopolysaccharide-induced lethal toxicity by tyrosine kinase inhibitors. Science 1994, 264, 1319-22.

(51) Vanichkin, A.; Patya, M.; Gazit, A.; Levitzki, A.; Novogrodsky, A. Late administration of a lipophilic tyrosine kinase inhibitor prevents lipopolysaccharide and Escherichia coli-induced lethal toxicity. J . Infect. Dis. 1996, 173, 927-33.

(52) Sevransky, J . E.; Shaked, G.; Novogrodsky, A.; Levitzki, A.; Gazit A.; Hoffman, A.; Elin, R. J .; Quezado, Z. M.; Freeman, B. D.; Eichacker, P. Q.; Danner, R. L.; Banks, S. M.; Bacher, J .; Thomas, M. L., 3rd; Natanson, C. Tyrphostin AG 556 improves survival and reduces multiorgan failure in canine Escherichia coli peritonitis. J. Clin. Invest. 1997, 99, 1966-73.

(53) Lopez-Talavera, J. C.; Levitzki, A.; Martinez, M.; Gazit, A.; Esteban, R.; Guardia, J . Tyrosine kinase inhibition ameliorates the hyperdynamic state and decreases nitric oxide production in cirrhotic rats with portal hypertension and ascites. J. Clin. Invest. 1997, $100,664-70$.

(54) Blum, G.; Gazit, A.; Levitzki, A. Catechol bioisosteres substrate competitive inhibitors of IGF-1R. Submitted 2003.

(55) Blum, G.; Gazit, A.; Levitzki, A. Substrate competitive inhibitors of IGF-1 receptor kinase. Biochemistry 2000, 39, 15705-12.

(56) Karni, R.; Levitzki, A. pp60(cSrc) is a caspase-3 substrate and Is essential for the transformed phenotype of A431 cells. Mol. Cell Biol. Res. Commun. 2000, 3, 98-104.

(57) Hanke, J. H.; Gardner, J . P.; Dow, R. L.; Changelian, P. S.; Brissette, W. H.; Weringer, E. J .; Pollok, B. A.; Connelly, P. A. Discovery of a novel, potent, and Src family-selective tyrosine kinase inhibitor Study of Lck- and FynT-dependent T cell activation. J . Biol. Chem. 1996, 271, 695-701.

(58) Karni, R.; J ove, R.; Levitzki, A. Inhibition of pp60c-Src reduces Bcl$\mathrm{XL}$ expression and reverses the transformed phenotype of cells overexpressing EGF and HER-2 receptors. Oncogene 1999, 18, 4654-62.

(59) Posner, I.; Engel, M.; Gazit, A.; Levitzki, A. Kinetics of inhibition by tyrphostins of the tyrosine kinase activity of the epidermal growth factor receptor and analysis by a new computer program. Mol. Pharmacol. 1994, 45, 673-83. 
(60) Benhar, M.; I., D.; D., E.; A., L. Enhanced ROS production in oncogenically transformed cells potentiates c-J un $\mathrm{N}$-terminal kinase and p38 mitogen-activated protein kinase activation and sensitization to genotoxic stress. Mol. Cell Biol. 2001, 21, 691326.

(61) Dvir, A.; Milner, Y.; Chomsky, O.; Gilon, C.; Gazit, A.; Levitzki, A. The inhibition of EGF-dependent proliferation of keratinocytes by tyrphostin tyrosine kinase blockers. J . Cell Biol. 1991, 113, 85765.

(62) Ben-Bassat H.; Vardi D. V.; Gazit A.; Klaus S. N.; Chaouat M.; Hartzstark Z.; Levitzki A. Tyrphostins suppress the growth of psoriatic keratinocytes. Exp. Dermatol. 1995, 4, 82-8.

(63) Ben-Bassat H.; Levitzki A. Inhibitors of tyrosine kinases in the treatment of psoriasis. Isr. Med. Assoc. J . 2000, 2 Suppl, 6973.

(64) Powell, T. J .; Ben-Bassat, H.; Klein, B. Y.; Chen, H.; Shenoy, N.; McCollough, J .; Narog, B.; Gazit, A.; Harzstark, Z.; Chaouat, M.; Levitzki, R.; Tang, C.; McMahon, J : Shawver, L.; Levitzki, A. Growth inhibition of psoriatic keratinocytes by quinazoline tyrosine kinase inhibitors. Br. J . Dermatol. 1999, 141, 802-10.

(65) Ben-Bassat H.: Rosenbaum-Mitrani S.; Hartzstark Z; Shlomai Z. Kleinberger-Doron N.; Gazit A.; Plowman G.; Levitzki R.; Tsvieli R.; Levitzki A. Inhibitors of epidermal growth factor receptor kinase and of cyclin-dependent kinase 2 activation induce growth arrest, differentiation, and apoptosis of human papilloma virus 16-immortalized human keratinocytes. Cancer Res. 1997, 57, 3741-50.

(66) Ben-Bassat H.; Rosenbaum-Mitrani S.; Hartzstark Z.; Levitzki R.; Chaouat M.; Shlomai Z.; Klein B. Y.; Kleinberger-Doron N.; Gazit A.; Tsvieli, R.; Levitzki A. Tyrphostins that suppress the growth of human papilloma virus 16-immortalized human keratinocytes. J. Pharmacol. Exp. Ther. 1999, 290, 1442-57.

(67) Ortu, G.; Ben David, I.; Rozen, Y.; Freedman, N. M.; Chisin, R. Levitzki, A.; Mishani, E. In vitro and in vivo investigation of an irreversible labeled EGFR inhibitor (ML03) and its potential as PET biomarker in Cancer and feasibility as an anticancer drug. Int. J . Cancer, in press.

(68) Bonasera, T. A.; Ortu, G.; Rozen, Y.; Krais, R.; Freedman, N. M.; Chisin, R.; Gazit, A.; Levitzki, A.; Mishani, E. Potential (18)F-labeled biomarkers for epidermal growth factor receptor tyrosine kinase. Nucl. Med. Biol. 2001, 28, 359-74.

(69) Davies, H.; Bignell, G. R.; Cox, C.; Stephens, P.; Edkins, S.; Clegg S.; Teague, J .; Woffendin, H.; Garnett, M. J .; Bottomley, W.; Davis, N.; Dicks, E.; Ewing, R.; Floyd, Y.; Gray, K.; Hall, S.; Hawes, R.; Hughes, J .; Kosmidou, V.; Menzies, A.; Mould, C.; Parker, A.; Stevens, C.; Watt, S.; Hooper, S.; Wilson, R.; J ayatilake, H.; Gusterson, B. A.; Cooper, C.; Shipley, J .; Hargrave, D.; PritchardJ ones, K.; Maitland, N.; Chenevix-Trench, G.; Riggins, G. J .; Bigner, D. D.; Palmieri, G.; Cossu, A.; Flanagan, A.; Nicholson, A.; Ho, J. W.; Leung, S. Y.; Yuen, S. T.; Weber, B. L.; Seigler, H. F.; Darrow, T. L.; Paterson, H.; Marais, R.; Marshall, C.J .; Wooster, R.; Stratton, M. R.; Futreal, P. A. Mutations of the BRAF gene in human cancer. Nature 2002, 417, 949-54.

(70) Lyons, J . F.; Wilhelm S.; Hibner, B.; Bollag, G. Discovery of a novel Raf kinase inhibitor. Endocr. Relat. Cancer 2001, 3, 219-225.
(71) Sebolt-Leopold, J . S.; Dudley, D. T.; Herrera, R.; Van Becelaere K.; Wiland, A.; R. C., G.; Tecle, H.; Barrett, S. D.; Bridges, A. Przybranowski, S.; Leopold, W. R.; Saltiel, A. R. Blockade of the MAP kinase pathway suppresses growth of colon tumors in vivo. Nat. Med. 1999, 5, 810-6.

(72) Sausville, E. A.; J ohnson, J .; Alley, M.; Zaharevitz, D.; Senderowicz, A. M. Inhibition of CDKs as a therapeutic modality. Ann. N.Y. Acad Sci. 2000, discussion, 221-2.

(73) Kaubisch, A.; Schwartz, G. K. Cyclin-dependent kinase and protein kinase $C$ inhibitors: a novel class of antineoplastic agents in clinical development. Cancer J. 2000, 6, 192-212.

(74) Mani, S.; Wang, C.; Wu, K.; Francis, R.; Pestell, R. Cyclin-dependent kinase inhibitors: novel anticancer agents. Expert Opin. Investig. Drugs 2000, 9, 1849-70.

(75) Murthi, K. K.; Dubay, M.; McClure, C.; Brizuela, L.; Boisclair, M D.; Worland, P. J .; Mansuri, M. M.; Pal, K. Structure-activity relationship studies of flavopiridol analogues. Bioorg. Med. Chem. Lett. 2000, 10, 1037-41.

(76) Roy, K. K.; Sausville, E. A. Early development of cyclin dependent kinase modulators. Curr. Pharm. Des. 2001, 7, 1669-87.

(77) Sausville, E. A. Complexities in the development of cyclindependent kinase inhibitor drugs. Trends Mol. Med. 2002, 8, S327.

(78) Kelland, L. R. Flavopiridol, the first cyclin-dependent kinase inhibitor to enter the clinic: current status. Expert Opin. Investig. Drugs 2000, 9, 2903-11.

(79) Senderowicz, A. M. Flavopiridol: the first cyclin-dependent kinase inhibitor in human clinical trials. Invest. New Drugs 1999, 17, 31320.

80) Reuveni, H.; Livnah, N.; Geiger, T.; Klen, S.; Ohne, O.; Cohen, I; Benhar, M.; Gellerman, G.; Levitzki, A. Towards a PKB inhibitor: Modification of a selective PKA inhibitor by rational design. Biochemistry, in press.

(81) da Rocha A. B.; Mans D. R.; Regner A.; Schwartsmann G. Targeting protein kinase $C$ : new therapeutic opportunities against high-grade malignant gliomas? Oncologist 2002, 7, 17-33.

(82) Goekjian, P. G.; J irousek, M. R. Protein kinase C inhibitors as novel anticancer drugs. Expert Opin. Investig. Drugs 2001, 10, 211740.

(83) Teicher, B. A.; Alvarez, E.; Menon, K.; Esterman, M. A.; Considine E.; Shih, C.; Faul, M. M. Antiangiogenic effects of a protein kinase Cbeta-selective small molecule. Cancer Chemother. Pharmacol. 2002, 49, 69-77.

(84) Ishii, H.; J irousek, M. R.; Koya, D.; Takagi, C.; Xia, P.; Clermont, A.; Bursell, S. E.; Kern, T. S.; Ballas, L. M.; Heath, W. F.; Stramm L. E.; Feener, E. P.; King, G. L. Amelioration of vascular dysfunctions in diabetic rats by an oral PKC beta inhibitor. Science $\mathbf{1 9 9 6}$ $272,728-31$

(85) Guba, M.; von Breitenbuch, P.; Steinbauer, M.; Koehl, G.; Flegel S.; Hornung, M.; Bruns, C. J .; Zuelke, C.; Farkas, S.; Anthuber, M.; J auch, K. W.; Geissler, E. K. Rapamycin inhibits primary and metastatic tumor growth by antiangiogenesis: involvement of vascular endothelial growth factor. Nat. Med. 2002, 8, 128-135. 